\title{
Oligotrophication and emergence of picocyanobacteria and a toxic dinoflagellate in Thau lagoon, southern France
}

\author{
Yves Collos ${ }^{a,{ }^{*}}$, Béatrice Bec ${ }^{a}$, Cécile Jauzein ${ }^{a, b}$, Eric Abadie ${ }^{b}$, Thierry Laugier ${ }^{b}$, Jacques \\ Lautier $^{a}$, Annie Pastoureaud ${ }^{b}$, Philippe Souchu ${ }^{b}$ and André Vaquer ${ }^{a}$
}

\author{
a Université Montpellier 2, CNRS, Ifremer, UMR 5119 Ecosystèmes Lagunaires, CC093, 34095 Montpellier Cedex \\ 5, France \\ ${ }^{\mathrm{b}}$ Ifremer, Laboratoire Environnement Ressources/LR, BP 171, Bd. Jean Monnet, 34203 Sète, France
}

*: Corresponding author : Yves Collos, email address : collos@univ-montp2.fr

\begin{abstract}
:
Time series data have been examined in Thau lagoon (Southern France) from 1972 to 2006 for water temperature, salinity, nutrients and from 1987 to 2006 for phytoplankton. A first main trend identified is an increase in mean annual water temperature $\left(1.5^{\circ} \mathrm{C}\right.$ over 33 years or $0.045^{\circ} \mathrm{C} /$ year) that was not evenly distributed among seasons. The highest rate of increase was in the spring $\left(+3.0^{\circ} \mathrm{C}\right.$ over 33 years), followed by summer $\left(+2.0^{\circ} \mathrm{C}\right)$ and fall $\left(+1.7^{\circ} \mathrm{C}\right)$. In winter, no significant increase over the 33 year period could be found. A second clear trend is a large decrease in soluble reactive phosphorus (SRP) concentration over the same 33 year period (summer values decreased from $10 \mu \mathrm{M}$ to $1 \mu \mathrm{M}$, while winter values decreased from $3 \mu \mathrm{M}$ to undetectable at present). Nitrate concentrations depended mainly on rainfall events and watershed runoff. Ammonium data were too fragmentary to be useful. N/P ratios expressed the traditional way of DIN/SRP cannot be used for phytoplankton that are not strict autotrophs. The recent and almost simultaneous appearance of both picocyanobacteria (mostly Synechococcus) and the toxic dinoflagellate Alexandrium catenella in Thau seem to be related to reduced nutrient loading and the increase in water temperature. $A$. catenella blooms occur either in the spring or the fall when water temperature is near $20^{\circ} \mathrm{C}$ and remains so for several weeks with winds speeds below $2-3 \mathrm{~m} \mathrm{~s}^{-1}$. Picocyanobacterial growth is stimulated by increased summer temperatures, and lowered SRP levels provide picocyanobacteria an ecological advantage over other phytoplankton classes, in particular diatoms such as Skeletonema costatum whose cell densities have decreased over the last 8 years in summer and fall, but not in winter. An hypothesis is presented according to which $A$. catenella is not stimulated by increased temperatures, but is able to use picocyanobacteria for growth, and this provides this organism an additional resource over other strictly autotrophic phytoplankton. On a more general level, our data do not support the hypothesis that increased nutrient loading leads to harmful blooms of dinoflagellates. Instead, a combination of habitat disturbance and species displacement seems to lead to such blooms.
\end{abstract}


1 Keywords : Thau lagoon ; long term variability ; oligotrophication ; picocyanobacteria ;

2 Alexandrium catenella; Skeletonema costatum

3 Regional index term : Mediterranean

4

1. Introduction

6

The recent increase in harmful algal blooms (HAB) in coastal areas is generally attributed to eutrophication. However, the cause-effect relationship is not always well established (Taylor et al., 1994; Smayda, 1997; Sellner et al., 2003). The main problem in relating $\mathrm{HAB}$ to environmental factors is that we lack a long term perpective on the occurrence of such blooms (Maso and Garcés, 2006). Time series data are important to understand processes and scales of phytoplankton variability and have revealed impacts of both increasing (Cloern, 2001; Cadée and Hegeman, 2002; Smith, 2006) and decreasing (Ruggiu et al., 1998; Anderson et al., 2002; Philippart et al., 2007) nutrient loads and concentrations on phytoplankton dynamics, sometimes with unexpected results. For example, in the Seto Inland Sea, reductions in nutrient load led to a decrease in phytoplankton biomass, but also to an increase in toxic phytoplankton species (Anderson et al., 2002 ; Imai et al., 2006).

The Thau lagoon has been recently invaded by a toxic dinoflagellate, Alexandrium catenella (Lilly et al., 2002) that is affecting economically important aquaculture activities such as oyster farming. Recent studies have focused on the nitrogenous nutrition of this dinoflagellate (Collos et al., 2004 ; 2006) and its ability to retrieve the limiting resources from this environment. Based on their results of growth kinetics under inorganic nitrogen $(\mathrm{N})$ or phosphorus (P) limitation, Matsuda et al. (1999) suggested that A. catenella could not become dominant in waters subjected to inorganic $\mathrm{N}$ or $\mathrm{P}$ limitation. It is therefore a paradox that $A$. 
1 catenella blooms occur in Thau Lagoon where dissolved inorganic $\mathrm{N}$ or $\mathrm{P}$ are limiting most of

2 the time (Collos et al., 1997; Souchu et al., 1998 ; 2001).

3 Here we place this recent phenomenon in a wider context using a long term data base on

4 physical, chemical and biological factors that have evolved over the last 30 years.

6 2. Material and methods

7 2.1. Study site

The Thau lagoon is a shallow marine lagoon located on the French Mediterranean coast $\left(43^{\circ} 24^{\prime} \mathrm{N}-3^{\circ} 36^{\prime} \mathrm{E}\right)$ covering $75 \mathrm{~km}^{2}$ (Fig. 1). It has a mean depth of $4 \mathrm{~m}$, with a maximum

10 depth of $10 \mathrm{~m}$. The lagoon is connected to the sea by 3 narrow channels. Three oyster farming 11 zones are located along the northwestern shore. The lagoon represents $10 \%$ of French oyster

12 production and is the main oyster production center on the Mediterranean. Since 1998, it has experienced recurrent blooms of Alexandrium catenella that periodically threaten economic

14 activities.

\subsection{Physical variables}

16 The Ifremer observation network provided records of surface water temperature and salinity

17 (monthly means). Over the study period, the number of stations ranged from 2 to 11.

18 Sampling frequency varied from 1 to 8 samples per month. Rainfall values (monthly means)

19 on the watershed were obtained from the National Meteorological Board local station of Sète

20 (Fig. 1). North Atlantic Oscillation (NAO) index values were obtained from

21 http://www.cgd.ucar.edu/cas/jhurrell/indices.data.html\#naostatseas.

22 Western Mediterranean Oscillation (WeMO) index values were obtained from

23 http://www.ub.es/gc/English/wemo.htm. The latter index corresponds to the surface

24 atmospheric pressure difference between Padua (Italy) and San Fernando (Spain). The Thau 
1 lagoon being located about half-way between those two points, local weather patterns are

2 likely to be influenced by such pressure differences.

\subsection{Nutrients}

4 Samples for ammonium determination were immediately fixed and measured at the laboratory

5 using the method of Koroleff (1976). Nitrate was measured according to Wood et al. (1967),

6 nitrite according to Bendschneider and Robinson (1952), soluble reactive phosphorus (SRP)

7 according to Murphy and Riley (1962), and silicate according to Mullin and Riley (1955).

8 Potential nutrient limitation was assessed according to the criteria of Justic et al. (1995) :

$9 \quad \mathrm{~N}$ limitation: $\mathrm{DIN}<1 \mu \mathrm{M} ; \mathrm{DIN} / \mathrm{SRP}<10$; $\mathrm{Si} / \mathrm{DIN}>1$

10 P limitation: $\mathrm{SRP}<0.1 \mu \mathrm{M} ; \mathrm{DIN} / \mathrm{SRP}>22 ; \mathrm{Si} / \mathrm{SRP}>22$

11 Si limitation: $\mathrm{Si}<2 \mu \mathrm{M}$; Si/SRP $<10$; Si/DIN $<1$

12 2.4. Biological variables

13 Chlorophyll a was estimated from $90 \%$ acetone extracts and fluorimetry (Holm-Hansen et al.

14 1965) or spectrofluorometry (Neveux and Lantoine, 1993).

15 Picophytoplankton abundances were estimated by flow cytometry. From 1990 to 1996,

16 samples were analyzed with a Bruker Spectrospin ACR-1400-SP fitted with a mercury arc

17 lamp and a $365 \mathrm{~nm}$ band-pass filter (Vaquer et al. 1996). From 1996 on, a Becton Dickinson

18 FACSCalibur flow cytometer, fitted with a $488 \mathrm{~nm}$ laser was used. Samples (1000 $\mu \mathrm{l})$ were

19 fixed by $2 \%$ (final concentration) formaldehyde (Troussellier et al., 1995) and stored in liquid

20 nitrogen. Eukaryotic phytoplankton cells were discriminated on the basis of light diffraction

21 (FSC Forward Scatter, related to cell size) and red fluorescence emissions (chlorophyll $a$,

22 wavelength $>650 \mathrm{~nm}$ ). Picocyanobacteria were identified by their orange fluorescence

23 emissions (phycoerythrin, 542-585 nm). All samples were analyzed with a mixture of

24 fluorescent beads of 0.96 and $1.8 \mu \mathrm{m}$ diameter ("Fluoresbrite" YG beads, Polysciences, Inc.,

25 Warrington, PA) in order to normalize all parameters and to discriminate pico- and 
1 nanophytoplankton. Duplicate subsamples acquisitions were run for 6 min and were

2 performed at a medium rate $\left(25-30 \mu 1 \mathrm{~min}^{-1}\right)$. Data were logged using CellQuest software, and

3 analyzed with "AttractorsTM" software (Becton Dickinson, Inc., USA).

4 The identification of Synechococcus was done by electron microscopy.

5 Nano-microphytoplankton. The REPHY Ifremer network started monitoring the Thau lagoon

6 for phytoplankton cells greater than $10 \mu \mathrm{m}$ equivalent cell diameter and toxic species in 1987

7 by optical microscopy. Sampling was carried out at least twice a month at station B.

8 Approximately 900 samples were analyzed for this time series.

9

10 3. Results

$11 \quad 3.1$ Physical variables

12 Individual water temperature values ranged from 4 to $29{ }^{\circ} \mathrm{C}$. Mean annual values ranged from 1313.8 (1980) to $16.7^{\circ} \mathrm{C}$ (2003). Over the 33 year period, the increase was significant and about $141.5^{\circ} \mathrm{C}$, or $0.045^{\circ} \mathrm{C} /$ year. But this increase was not evenly distributed among seasons (Fig. 2).

15 On a seasonal basis, the highest rate of increase was in the spring $\left(+3.0^{\circ} \mathrm{C}\right.$ over 33 years $)$,

16 followed by summer $\left(+2.0^{\circ} \mathrm{C}\right)$ and fall $\left(+1.7^{\circ} \mathrm{C}\right)$. In winter, no significant increase over the 33 17 year period could be found.

18 Concerning mean monthly values, a significant negative correlation between temperature 19 anomalies and the WeMO index could be found $\left(r^{2}=0.051, n=321, p<0.01\right)$. The correlation 20 was strongest for the month of May $\left(r^{2}=0.370, n=23, p<0.01\right)$. No overall relationship could 21 be found with the NAO index, but in July, temperature anomalies were positively and 22 significantly correlated with NAO values.

23 Individual salinity values ranged from 28.5 to 40.0. Mean annual values ranged from 32.6 to 2438.0 , with no apparent trend over the period, but those values were positively correlated with 25 the NAO winter index in a highly significant way $\left(\mathrm{r}^{2}=0.378, \mathrm{n}=31, \mathrm{p}<0.01\right)$. 
1 Mean annual rainfall values ranged from $279 \mathrm{~mm} / \mathrm{year}$ in 1998 to $1310 \mathrm{~mm} / \mathrm{year}$ in 1990, with

2 no apparent trend over the period. Monthly values ranged from zero in January 1983 to 342

$3 \mathrm{~mm} / \mathrm{month}$ in October 1979. No relationship could be found with the NAO index. But the

4 rainiest months (> $310 \mathrm{~mm} /$ month) were associated with negative WeMO index values.

$6 \quad 3.2$ Nutrients

7 Data on ammonium concentrations were fragmentary. From several published data sets

8 (Casellas et al., 1990; Collos et al., 1997, 2005a; Souchu et al., 2001), a seasonal trend could

9 be identified with high (above $5 \mu \mathrm{M}$, and up to $10 \mu \mathrm{M}$ ) values in the fall (September to

10 November) and low (less that $2 \mu \mathrm{M}$ ) during the rest of the year. Nitrate ranged between

11 undetectable $(<0.05 \mu \mathrm{M})$ and $22 \mu \mathrm{M}$, with no long term temporal trend. The nitrate

12 concentrations were closely related to rainfall events (Fig. 3). The Thau ecosystem functions

13 most of the year as a continuous culture with a low background of phytoplankton biomass as

$14 \mathrm{Chl} \mathrm{a}(0.1-2 \mu \mathrm{g} / \mathrm{l})$ growing on regenerated production. Following rainfall events, a nutrient

15 pulse arrives from the watershed in the lagoon and triggers a phytoplankton bloom using

16 nitrate as a N source such as during the November 1993 Thalassiosira bloom (Collos et al.

17 1997). Silicate ranged between 0.4 and $43 \mu \mathrm{M}$, with no temporal trend. Soluble reactive

18 phosphorus (SRP) ranged between undetectable and $10 \mu \mathrm{M}$ over the 30 year period. There

19 was a steady decline in concentrations with time (Fig. 4) due to efforts to reduce

20 eutrophication. Superimposed on this general trend were seasonal trends with SRP peaks in

21 summer due to release from sediment enhanced by temperature (Mazouni et al. 1996). But

22 overall, a large decrease in SRP concentrations occurred over the 30 year period. Summer

23 values decreased from $10 \mu \mathrm{M}$ to $1 \mu \mathrm{M}$ while winter values decreased from $3 \mu \mathrm{M}$ to

24 undetectable $(<0.03 \mu \mathrm{M})$ at present. 
1 Individual values of NO3/SRP over 30 years ranged between 0.05 and 27.7 without any

2 apparent trend. There was a clear seasonal trend in DIN/SRP ratios whose range matched long

3 term trends in NO3/SRP ratios. For example, in 1993, low DIN/SRP values (0.4-0.5) were

4 recorded in summer. DIN ranged from 0.4 to $0.5 \mu \mathrm{M}$ and SRP from 1.0 to $1.1 \mu \mathrm{M}$, indicating

$5 \quad \mathrm{~N}$ limitation according to the criteria of Justic et al. (1995). In winter, high DIN/SRP values (8

6 to 29 ) were observed. DIN ranged from 1.7 to $4.6 \mu \mathrm{M}$ and SRP was around $0.2 \mu \mathrm{M}$,

7 indicating no limitation by either $\mathrm{N}$ or $\mathrm{P}$ according to the same criteria.

$9 \quad 3.3$ Phytoplankton

11 Cyanobacteria

12 Between November 1991 and February 1994 a monthly sampling program recorded mean

13 values between 19 and $192 \times 10^{3}$ cells/l (mean from 5 stations in Thau lagoon), but much

14 higher values (around $5000 \times 10^{3}$ cells/l) at one reference station in the Mediterranean Sea

15 (Vaquer et al. 1996). By 1998-1999, maximum cell densities reached 400-700 x 10³ cells/l

16 (mean from 4 stations in Thau lagoon). Cell densities remained around those values until the

17 summer of 2003 when individual values up to $11 \times 10^{8}$ cells/1 and mean values up to $400 \times 10^{6}$

18 cells/l were observed (Fig. 4). Most of these were of the Synechococcus genus, as identified

19 by electron microscopy.

21 Diatoms

22 The main planktonic genera present in Thau lagoon were Asterionellopsis, Chaetoceros,

23 Ditylum, Pseudo-nitzschia, Rhizosolenia, Skeletonema costatum, Thalassionema and

24 Thalassiosira. Mean annual cell densities of S. costatum reached a peak of about 2,000

25 cells/ml in 1996, corresponding to a record low NAO winter index (-3.78). Cell densities then 
1 steadily declined over the next 10 years to reach 7 cells $/ \mathrm{ml}$ in 2005 . However, the decline was

2 not evenly distributed and was more pronounced in spring, summer and fall than in winter

3 (Table 1). The other genera did not show such trends.

\section{Alexandrium catenella}

6 First reports of this species were made in 1995 (20,000 cells/1), following 8 years of

7 monitoring without observation of this species. The first toxic event was reported in 1998

8 (Lilly et al. 2002). Thereafter, maximum cell densities increased with time until 2004, up to

$915 \times 10^{6}$ cells/l (Fig. 4), with more pronounced blooms in the fall than in the spring.

4. Discussion

The long term increase in mean annual water temperature is similar to that found in other coastal environments at similar latitudes (Ohtaki et al., 1992 ; Soletchnik et al., 1998; Goffart et al., 2002). For example, in the Seto Inland Sea, the annual increases in air and water temperature were 0.07 and $0.06{ }^{\circ} \mathrm{C} /$ year respectively (Ohtaki et al., 1992) over the period 1970-1989. However, it is not so much mean annual values rather than values recorded over smaller time scales such as the seasonal ones (Fig. 2), that appear to be important for phytoplankton, as will become evident below.

Mean annual salinity was correlated with the NAO winter index in a highly significant way. However, neither mean annual or seasonal water temperature, nor rainfall were correlated with NAO. There was no correlation between rainfall and salinity, indicating that it is probably a balance between evaporation, rainfall and exchanges with the Mediterranean Sea that controls salinity in Thau lagoon, or that rainfall data are not representative of the situation in the watershed. Possibly, the low inertia of this shallow environment (mean depth $=4 \mathrm{~m}$ ) 
1 regarding water temperature makes it less sensitive to farfield (climate) influences and more

2 dependent on local weather conditions. The correlation between temperature anomalies and

3 the WeMO index values, similar to that found in the Gulf of Valencia (Martin-Vide and

4 Lopez-Bustins, 2006), supports this possibility.

5 Ammonium data were too fragmentary to be used on the long term. From results of a seasonal

6 study with monthly sampling, ammonium could be related to the phaeophytin a/chlorophyll a

7 ratio (Collos et al., 2005a) and the relationship was interpreted as a general decomposition of

8 phytoplankton communities during fall. The lack of continuous ammonium data also

9 prevented us from using the DIN/SRP ratio, specially as ammonium could represent $100 \%$ of

10 DIN at times. In as much as A. catenella is known to use urea and possibly other organic $\mathrm{N}$

11 compounds as N sources (Carlsson et al., 1998; Dyhrman and Anderson, 2003; Collos et al.,

12 2004; Jeong et al. 2005), as well as organic P (Matsuda et al., 1999), the use of the N/P ratio

13 under the traditional form of DIN/SRP does not seem applicable to this species or other

14 phytoplankton species that are not strict autotrophs. Irmish (1991) has shown that adding urea

15 to the DIN could change the N/P ratios in the Baltic Sea by a factor of 3 to 7.

16 Probably the most useful data set is the one shown in Fig. 4, where low to undetectable

17 SRP concentrations coincided with the appearance of picocyanobacteria (around 1994) and $A$.

18 catenella (around 1995). The decrease in SRP was due mainly to the implementation of

19 sewage treatment plants in the 1970s (La Jeunesse and Elliott, 2004). Phosphorus stored in

20 shellfish represented about $20 \%$ of total inputs by human activities, and the contribution of

21 shellfish to limiting eutrophication is probably maximal due to current legal limits on the area

22 allocated to shellfish farming (La Jeunesse and Elliott, 2004). The simultaneous

23 oligotrophication and appearance of A. catenella blooms in Thau lagoon bear a striking

24 similarity to events in the Seto Inland Sea where, citing Anderson et al. (1992) : « as the

25 waters became less eutrophic and large biomass blooms decreased, there was a shift in species 
1 composition, leading to a greater prevalence of some that are responsible for shellfish

2 poisonings in humans, such as Alexandrium tamarense and A. catenella ».

Among a series of marine Mediterranean lagoons that can be ordered along a

4 eutrophication gradient characterized by chlorophyll a and total phosphorus (Fig. 5), Thau

5 appears to be one of the less eutrophied ones, yet harbors a toxic dinoflagellate.

6 Biogeochemical aspects of this eutrophication gradient are being treated elsewhere (Souchu et

7 al., in preparation). A similar situation occurs in another local lagoon, Leucate, that is even

8 less eutrophied than Thau, but in which the toxic dinoflagellate Dinophysis acuminata blooms

9 recurrently (Le Bec et al., 1997). Thus it seems, at least from those two examples, that HABs

10 are not related to eutrophication of the Mediterranean coastal zone.

11 This led us to examine climate change as a possible driver of the recent development

12 of HABs in Thau lagoon. Concerning A. catenella, the occurrence of several blooms between

132000 and 2003 led us to look for a relationship between environmental variables and cell

14 densities. The relationship with surface temperature is shown in Fig. 6. It can be seen from

15 these data that, for a bloom to occur, there has to be a period during which surface

16 temperature remains near $20^{\circ} \mathrm{C}\left( \pm 1^{\circ} \mathrm{C}\right)$ and wind speed below $2-3 \mathrm{~m} \cdot \mathrm{s}^{-1}$. When the water

17 temperature increases rapidly in the spring, as in 2001, no bloom develops. The same

18 phenomenon occurs in the fall if the water temperature decreases too rapidly, as in 2002.

19 Therefore, the general long term increase in water temperature in Thau does not seem to have

20 a direct effect on A. catenella, since it is a physical window, identified so far by water

21 temperatures near $20^{\circ} \mathrm{C}$, that provides conditions for bloom development. This variable may

22 also act as a proxy for some other variable such as water column stability or turbulence.

23 Regarding the sensitivity of Alexandrium catenella to turbulence, results differ among

24 investigators (Sullivan et al., 2003; Collos et al., 2004; Bolli et al., 2007) probably reflecting

25 differences in experimental conditions. Our data indicate that wind events could act either 
1 directly on growth rate or dissipate the bloom by advection.

2 Concerning picocyanobacteria, there seems to be an effect of temperature on their

3 development. As shown in Fig. 7, while relatively low summer cell densities (below 100

4 cells/ $\mu \mathrm{l}$ ) were recorded before 2003, they increased about 10 times during the summer of 2003

5 when temperatures reached $28^{\circ} \mathrm{C}$ in August - the highest values recorded for the last 33 years.

6 Then in 2004, summer temperatures went back to below $25^{\circ} \mathrm{C}$ and picocyanobacterial cell

7 densities also decreased to previous levels. In 2006, the increasing trend was reproduced.

8 Hence, there appears to be a clear threshold effect of temperature on picocyanobacterial

9 abundance in Thau lagoon. These results are consistent with previous findings that showed

10 picocyanobacterial gross growth rates in Thau Lagoon are related to water temperature in a

11 significant way (Bec et al., 2005).

12 Another factor possibly contributing to picocyanobacterial development is the lowered SRP

13 concentration in recent years. Table 2 summarizes a literature review of half-saturation

14 constants (Ks) for SRP uptake by several classes of phytoplankton. Such comparisons are

15 fraught with difficulties : apart from differences in experimental conditions, one problem is

16 the possibility of multiphasic uptake of SRP that is common in unicellular algae (Jeanjean et

17 al., 1970; Rivkin and Swift, 1982; Jansson, 1993). As mentioned by Rivkin and Swift (1982),

18 "Direct curve fitting might not discriminate between the various phases and would therefore

19 overestimate both the Km and Vmax". In order to minimize those risks, and retain the phase

20 of uptake of ecological significance, we have selected those studies where the SRP addition

21 was $20 \mu \mathrm{M}$ at most. A second selection was done by rejecting studies using P sufficient cells.

22 When raw data were available, and visual inspection revealed multiphasic kinetics, Ks were

23 recalculated as in Collos et al. (2005b). When several Ks values were obtained for one species

24 (at several dilution rates for example), only the average value was retained in order to weigh

25 each species equally. The data set obtained is not exhaustive, but is probably representative of 
1 the published studies on that topic. Freshwater and marine data were pooled. For the

2 Chlorophyceae, freshwater species represented $95 \%$ of the data. For the Cyanophyceae, there

3 were 8 marine studies and 12 freshwater ones, without significant differences in Ks. However,

4 Ks of freshwater Synechococcus (mean of $0.17 \mu \mathrm{M}$ for $\mathrm{n}=6$ ) were much lower than those of

5 marine Synechococcus (mean of $0.94 \mu \mathrm{M}$ for $\mathrm{n}=4$ ). This difference comes mainly from the

6 high Ks value for Synechococcus WB7803 (Donald et al. 1997) which may be due to

7 methodological biases since more recent studies indicate Ks as low as $0.13 \mu \mathrm{M}$ for the same

8 strain (Scanlan, 2003). Recent evidence from natural populations of Synechococcus from the

9 Mediterranean (Moutin et al., 2002; Tanaka et al., 2003) indicate Ks values for SRP uptake lie

10 between 0.02 and $0.05 \mu \mathrm{M}$.

11 For some members of the phytoplankton, the number of cases documented in Table 2 is

12 clearly not sufficient to draw meaningful conclusions. But for at least the first four classes, it

13 is clear that cyanobacteria, and more particularly picocyanobacteria such as Synechococcus,

14 appear to be well equipped to scavenge low levels of SRP from the environment.

15 The development of picocyanobacteria upon or following decreases in SRP has also been

16 reported from other aquatic environments. For example, in Lago Maggiore (Italy), autotrophic

17 picoplankton, mainly Synechococcus, developed following oligotrophication of the lake

18 (Ruggiu et al., 1998; Callieri and Piscia, 2002). In Saidenbach Reservoir (Germany), the

19 decrease in SRP induced a development of cyanobacteria in summer at the expense of diatoms

20 (Horn, 2003). In both cases, the maximum SRP levels during the eutrophication phase were

21 much lower than those experienced in Thau (1 and $0.5 \mu \mathrm{M}$ respectively in Lago Maggiore and

22 Saidenbach Reservoir), but the levels corresponding to cyanobacteria development were

23 similar to those in Thau lagoon (0.25 and $0.07 \mu \mathrm{M}$, respectively).

24 The decrease in mean annual cell numbers of S. costatum (Fig. 4) in Thau lagoon over

25 the last ten years is particularly striking as it ranges over almost 3 orders of magnitude (from 
12,600 down to 7 cells $/ \mathrm{ml}$ ) and it is concurrent with the increase in picocyanobacteria and $A$.

2 catenella. Those opposing trends suggest species interactions between $S$. costatum and either 3 picocyanobacteria or A. catenella. For example, in 1993, S. costatum was dominant in June

4 and $\mathrm{N}$ uptake measurements showed that it was well adapted to the nutrient regime (Collos et 5 al. 2003). However, the cell density of this species progressively decreased from 1996 on

6 (Fig. 4), but the decrease was not evenly spread among seasons. As shown in Table 1, during 7 the picocyanobacteria "explosive" phase (1999 on), the decrease in S. costatum was most 8 pronounced in spring (significant decrease, $\mathrm{p}<0.05$ ), summer (significant decrease, $\mathrm{p}<0.05$ ) or

9 fall, but not in winter. In as much as picocyanobacteria develop mostly in summer, it can be suggested that they displaced $S$. costatum during that season. In spring and fall, which are

11 seasons during which $A$. catenella blooms, this probably also contributed to the displacement 12 of $S$. costatum by taking up dissolved inorganic nutrients that were common ressources to 13 both species. The decrease in SRP therefore seems to have "closed" a niche (defined as a 14 resource, sensu Smayda, 2002, and here defined as SRP concentrations) to diatoms such as $S$. 15 costatum. Picocyanobacteria were able to outcompete and displace this previously dominant 16 species by their ability to exploit low SRP levels (Table 2). This situation is somewhat similar 17 to that in Saidenbach Reservoir (Horn, 2003) where the diatom Fragilaria crotonensis was 18 displaced by cyanobacteria when SRP levels fell below $0.1 \mu \mathrm{M}$.

19 Thus, the combination of two main controlling factors, temperature and SRP, that are 20 evolving in opposite directions could help explain the appearance and development of 21 picocyanobacteria such as Synechococcus in Thau lagoon.

22 Finally, there may be a trophic link that could also contribute to the quasi simultaneous 23 appearance of both picocyanobacteria and A. catenella in this environment. It was recently 24 shown that 17 species of dinoflagellates (including A. catenella) were able to graze upon the 25 picocyanobacterium Synechococcus (Jeong et al., 2005). Comparisons of N-based growth and 
1 N uptake rates by A. catenella (Collos et al., 2007) indicate that this species grew mainly on

2 ammonium and urea as $\mathrm{N}$ sources, but an unknown $\mathrm{N}$ source was periodically important and

3 had to be taken into account to support the observed growth rates. Particulate $\mathrm{N}$ in the form of

4 picocyanobacteria could therefore provide this supplement in limiting nutrient to A. catenella

5 and give it an ecological advantage over strictly autotrophic phytoplankton. Independently of

6 the direction of change in trophic status generally invoked, such a scenario is compatible with

7 the habitat disturbance hypothesis (Smayda, 2002) leading to HAB occurrences.

9 Acknowledgments

11 The present work was funded by CNRS (Centre National de la Recherche Scientifique) and 12 Ifremer (Institut Français de Recherche pour l'Exploitation de la Mer) ALTOX program. We 13 wish to thank Dr. Esther Garcés for useful comments on an early draft of the manuscript. This 14 work benefited from correspondence with Elisa Berdalet.

References

18 Anderson, D.M., Glibert, P.M., Burkholder, J.M., 2002. Harmful algal blooms and eutrophication: nutrient sources, composition, and consequences. Estuaries 25, 704-726.

20 Bec, B., Husseini-Ratrema, J., Collos, Y., Souchu, P., Vaquer, A., 2005. Phytoplankton

21 seasonal dynamics in a Mediterranean coastal lagoon: emphasis on the picoeukaryote 22 community. J. Plankton Res. 27, 881-894

23 Bendschneider, K., Robinson, R.J., 1952. A new spectrophotometric method for the 24 determination of nitrite in seawater. J. Mar. Res. 11, 87-96. 
1 Bolli, L., Llaveria, G., Garcés, E., Guadayol, O., van Lenning, K., Peters, F., Berdalet, E.,

2 2007. Modulation of ecdysal cyst and toxin dynamics of two Alexandrium (Dinophyceae)

3 species under small-scale turbulence. Biogeosciences Discuss. 4, 893-908.

4 Cadée, G.C., Hegeman, J., 2002. Phytoplankton in the Marsdiep at the end of the $20^{\text {th }}$ century:

530 years monitoring biomass, primary production, and Phaeocystis blooms. J. Sea Res. 48,

$6 \quad 97-110$.

7 Callieri, C, Piscia, R., 2002. Photosynthetic efficiency and seasonality of autotrophic picoplankton

8 in Lago Maggiore after its recovery. Freshwater Biol. 47, 941-956.

9 Casellas, C., Pena, G., Picot, B., Illes, S., Bontoux, J., 1990. Nutrients in Thau lagoon:

10 grouping of contiguous geographical zones. Water Res. 24, 1479-1489.

11 Cembella, A.D., Antia, N.J., Harrison, P.J., 1984. The utilization of inorganic and organic

12 phosphorus compounds as nutrients by eukaryotic microalgae: a multidisciplinary perspective: part

13 1. Crit. Rev. Microbiol. 10, 317-391.

14 Cloern, J.E., 2001. Our evolving conceptual model of the coastal eutrophication problem. Mar.

15 Ecol. Progr. Ser. 210, 223-253.

16 Collos, Y., Vaquer, A., Bibent, B., Slawyk, G., Garcia, N., Souchu, P., 1997. Variability in

17 nitrate uptake kinetics of phytoplankton communities in a Mediterranean coastal lagoon.

18 Estuar. Coastal Shelf Sci. 44, 369-375.

19 Collos, Y., Vaquer, A., Bibent, B., Souchu, P., Slawyk, G., Garcia, N., 2003. Responses of

20 coastal phytoplankton to ammonium and nitrate pulses: seasonal variations of uptake and

21 regeneration of nitrogenous nutrients. Aquatic Ecology 37, 227-236.

22 Collos, Y., Gagne, C., Laabir, M., Vaquer, A., Cecchi, P., Souchu, P., 2004. Nitrogenous

23 nutrition of Alexandrium catenella (Dinophyceae) in cultures and in Thau lagoon, southern

24 France. J. Phycol. 40, 96-103. 
1 Collos, Y., Husseini-Ratrema, J., Bec, B., Vaquer, A., Lam Hoai, T., Rougier, C., Pons, V.,

2 Souchu, P., 2005a. Pheopigment dynamics, zooplankton grazing rates and the autumnal

3 ammonium peak in a Mediterranean lagoon. Hydrobiol. 550, 83-93

4 Collos, Y., Vaquer, A., Souchu, P., 2005b. Acclimation of nitrate uptake by phytoplankton to

$5 \quad$ high substrate levels. J. Phycol. 41, 466-478.

6 Collos, Y., Lespilette, M., Vaquer, A., Laabir, M., Pastoureaud, A., 2006. Uptake and

7 accumulation of ammonium by Alexandrium catenella during nutrient pulses. Afr. J. Mar. Sci.

$8 \quad 28,313-318$.

9 Collos, Y., Vaquer, A., Laabir, M., Abadie, E., Laugier, T., Pastoureaud, A., Souchu, P.,

10 2007. Contribution of several nitrogen sources to growth of Alexandrium catenella during

11 blooms in Thau lagoon, Southern France. Harmful Algae 6, 781-789.

12 Donald, K.M., Scanlan, D.J., Mann, N.H., Joint, I., 1997. Comparative phosphorus nutrition

13 of the marine cyanobacterium Synechococcus WH7803 and the marine diatom Thalassiosira

14 weissflogii. J. Plankton Res. 19, 1793-1813.

15 Doremus, C, 1982. Geochemical control of dinitrogen fixation in the open ocean. Biol.

16 Oceanogr. 1, 429-436.

17 Duarte, C.M., 1995. Submerged aquatic vegetation in relation to different nutrient regimes.

18 Ophelia 41, 87-112.

19 Fu, F.-X., Zhang, Y., Bell, P.R.F., Hutchins, D.A., 2005. Phosphate and growth kinetics of

20 Trichodesmium (Cyanobacteria) isolates from the Northe Atrlantic Ocean and the Great Barrier

21 Reef, Australia. J. Phycol. 41, 62-73.

22 Fu, F.-X., Zhang, Y., Feng, Y., Hutchins, D.A., 2006. Phosphate and ATP uptake and growth

23 kinetics in axenic cultures of the cyanobacterium Synechococcus CCMP 1334. Eur. J. Phycol.

$24 \quad 41,15-28$. 
1 Goffart, A., Hecq, J.H., Legendre, L., 2002. Changes in the development of the winter-spring

2 phytoplankton bloom in the Bay of Calvi (NW Mediterranean) over the last two decades: a

3 response to changing climate ? Mar. Ecol. Prog. Ser. 236, 45-60.

4 Holm-Hansen, O., Lorenzen, C.J., Holmes, R.W., Strickland, J.D.H., 1965. Fluorometric

5 determination of chlorophyll. J. Cons. Perm. Int. Explor. Mer 30, 3-15.

6 Horn, H., 2003. The relative importance of climate and nutrients in controlling phytoplankton

7 growth in Saidenbach Reservoir. Hydrobiol. 504, 159-166.

8 Imai, I., Yamaguchi, M., Hori, Y., 2006. Eutrophication and occurrences of harmful algal

9 blooms in the Seto Inland Sea, Japan. Plankton Benthos Research 1, 71-84.

10 Irmisch, A., 1991. Investigations on the urea uptake by phytoplankton in the Baltic sea. Acta

11 Hydrochim. Hydrobiol. 19, 39-44.

12 Isvanovics, V., Shafik, H.M., Présing, M., Juhos, S., 2000. Growth and phosphate uptake

13 kinetics of the cyanobacterium, Cylindrospermopsis raciborskii (Cyanophyceae) in

14 throughflow cultures. Freshwater Biol. 43, 257-275.

15 Jansson, M., 1993. Uptake, exchange, and excretion of orthophosphate in phosphate-starved

16 Scenedesmus quadricauda and Pseudomonas K7. Limnol. Oceanogr. 38, 1162-78.

17 Jeanjean, R., Blasco, F., Gaudin, C., 1970. Etude des mécanismes d'absorption de l'ion

18 phosphate par les Chlorelles. C. R. Acad. Sci. (Paris) 270, 2946-2949.

19 Jeong, H.J., Park, J.Y., Nho, J.H., Park, M.O., Ha, J.H., Seong, K.A., Jeng, C., Seong, C.N.,

20 Lee, K.Y., Yih, W.H., 2005. Feeding by red-tide dinoflagellates on the cyanobacterium

21 Synechococcus. Aquatic Microb. Ecol. 41, 131-143.

22 Justic, D., Rabalais, N.N., Turner, R.E., Dortch, Q., 1995. Changes in nutrient structure of

23 river-dominated coastal waters - stoichiometric nutrient balance and its consequences.

24 Estuar. Coast. Shelf Sci. 40, 339-356.

25 Koroleff, F. 1976. Determination of nutrients. In: Grasshoff, K. (Ed.), Methods of Seawater 
1 Analysis, Verlag Chemie, Weinheim, pp. 117-182.

2 Kromkamp, J., Van den Heuvel, A., Mur, L.R., 1989. Phosphorus uptake and photosynthesis

3 by phosphate-limited cultures of the cyanobacterium Microcystis aeruginosa. Br. Phycol. J.

$4 \quad 24,347-355$.

5 La Jeunesse, I., Elliott, M., 2004. Anthropogenic regulation of the phosphorus balance in the

6 Thau catchment-coastal lagoon system (Mediterranean Sea, France) over 24 years. Mar. Poll.

$7 \quad$ Bull. 48, 679-687.

8 Le Bec, C., Belin, C., Gaertner, J.C., Beliaeff, Raffin, B., Ibanez, F., 1997. Séries temporelles

9 du réseau de surveillance du phytoplancton (REPHY). Etude de deux zones de la côte Ouest

10 Méditerranée. Oceanol. Acta 20, 101-108.

11 Lehman, J. T., Botkin, D.B., Likens, G.E., 1975. The assumptions and rationales of a

12 computer model of phytoplankton population dynamics. Limnol. Oceanogr. 20, 343-364.

13 Lilly, E.L., Kulis, D.M., Gentien, P., Anderson, D.M., 2002. Paralytic shellfish poisoning

14 toxins in France linked to a human-introduced strain of Alexandrium catenella from the

15 western Pacific: evidence from DNA and toxin analysis. J. Plankton Res. 24, 443-452.

16 Martin-Vide, J., Lopez-Bustins, J.A., 2006. The Western Mediterranean Oscillation and

17 rainfall in the Iberian Peninsula. Int. J. Climat. 26, 1455-1475.

18 Maso, M., Garcés, E., 2006. Harmful microalgae blooms (HAB); problematic and conditions

19 that induce them. Mar. Poll. Bull. 53, 620-630.

20 Matsuda, A., Nishijima, T., Fukami, K., 1999. Effects of nitrogenous and phosphorus

21 nutrients on the growth of toxic dinoflagellate Alexandrium catenella. Nippon Suisan

22 Gakkaishi 65, 847-855.

23 Mazouni, N., Gaertner, J.C., Deslous-Paoli, J.M., Landrein, S., Geringer d'Oedenberg, M.,

24 1996. Nutrient and oxygen exchanges at the water-sediment in a shellfish farming lagoon

25 (Thau, France). J. Exp. Mar. Biol. Ecol. 205, 91-113. 
1 Moutin, T., Thingstad, T.F., Van Wambeke, F., Marie, D., Slawyk, G., Raimbault, P.,

2 Claustre, H., 2002. Does competition for nanomolar phosphate supply explain the

3 predominance of the cyanobacterium Synechococcus ? Limnol. Oceanogr. 47: 1562-1567.

4 Moutin, T., Van Den Broeck, N., Beker, B., Dupouy, C., Rimmelin, P., Le Bouteiller, A.,

5 2005. Phosphate availability controls Trichodesmium spp. biomass in the SW Pacific Ocean.

6 Mar. Ecol. Prog. Ser. 297, 15-21.

7 Mullin, J.B., Riley, J.P., 1955. The colorimetric determination of silicate with special

8 reference to sea and natural waters. Anal. Chim. Acta 12, 162-176.

9 Murphy, J., Riley, J.P., 1962. A modified single solution method for the determination of

10 phosphate in natural waters. Anal. Chim. Acta 27, 31-36.

11 Nalewajko, C., Lean, D.R.S., 1980. Phosphorus. In: Morris, I. (Ed.), The physiological

12 ecology of phytoplankton. University of California Press, Berkeley, CA, pp. 235-258.

13 Neveux, J., Lantoine, F., 1993. Spectrofluorometric assay of chlorophylls and phaeopigments

14 using the least squares approximation technique. Deep-Sea Res. 40, 1747-1765.

15 Ohtaki, E., Yamashita, E., Fujiwara, F., 1992. Atmospheric carbon-dioxide variations at 16 coastal site, Sibukawa, in Seto Inland Sea, Japan. 2. Observation from 1980 to 1989. Theor.

17 Appl. Climatol. 45, 177-181.

18 Philippart, C.J.M., Beukema, J.J., Cadée, G.C., Dekker, R., Goedhart, P.W., Van Iperen, J.M.,

19 Leopold, M.F., Herman, P.M.J., 2007. Impacts of nutrient reduction on coastal communities.

20 Ecosystems 10, 95-118.

21 Rivkin, R. B., Swift, E., 1982. Phosphate uptake by the oceanic dinoflagellate Pyrocystis

22 noctiluca. J. Phycol. 18, 113-120.

23 Ruggiu, D., Morabito, G., Panzani, P., Pugnetti, A., 1998. Trends and relations among basic 24 phytoplankton characteristics in the course of the long-term oligotrophication of Lake

25 Maggiore (Italy). In: Alvarez-Cobelas, M., Reynolds, C.S., Sanchez-Castillo, P., Kristiansen, 
1 J. (Eds.), Phytoplankton and trophic gradients. Hydrobiol. 369/370, 243-257.

2 Scanlan, D.J., 2003. Physiological diversity and niche adaptation in marine Synechococcus.

3 Adv. Microb. Ecol. 47, 1-64.

4 Schramm, W., 1999. Factors influencing seaweed responses to eutrophication: some results

5 from EU-project EUMAC. J. Appl. Phycol. 11, 69-78.

6 Sellner, K.G., Doucette, G.J., Kirkpatrick, G.J., 2003. Harmful algal blooms: causes, impacts

7 and detection. J. Ind. Microbiol. Biotechnol. 30, 383-406.

8 Smayda, T.J., 1997. Harmful algal blooms: Their ecophysiology and general relevance to

9 phytoplankton blooms in the sea. Limnol. Oceanogr. 42, 1137-1153.

10 Smayda, T.J., 2002. Adaptive ecology, growth strategies and the global bloom expansion of

11 dinoflagellates. J. Oceanography 58, 281-294.

12 Smith, V.H., 2006. Responses of estuarine and coastal marine phytoplankton to nitrogen and

13 phosphorus enrichment. Limnol Oceanogr 51, 377-384.

14 Souchu, P., Gasc, A., Collos, Y., Vaquer, A., Tournier, H., Bibent, B., Deslous-Paoli, J.M., 15 1998. Biogeochemical aspects of bottom anoxia in a Mediterranean lagoon (Thau, France).

16 Mar. Ecol. Prog. Ser. 164, 135-146.

17 Souchu, P., Vaquer, A., Collos, Y., Landrein, S., Deslous-Paoli, J.M., Bibent, B., 2001.

18 Influence of shellfish farming activities on the biogeochemical composition of the water

19 column in Thau lagoon. Mar. Ecol. Prog. Ser. 218, 141-152.

20 Sullivan, J.M., Swift, E., Donaghay, P.L., Rines, J.E.B., 2003. Small-scale turbulence affects

21 the division rate and morphology of two red-tide dinoflagellates. Harmful Algae 2, 183-199.

22 Tanaka, T., Rassoulzadegan, F., Thingstad, T.F. 2003. Measurements of phosphate affinity

23 constants and phosphorus release rates from the microbial food web in Villefranche Bay,

24 northwestern Mediterranean. Limnol. Oceanogr. 48, 1150-1160. 
1 Taylor, F.J.R., Haigh, R., Sutherland, T.F., 1994. Phytoplankton ecology of Sechelt Inlet, a

2 fjord system on the British Columbia coast. II. Potentially harmful species. Mar. Ecol. Progr.

3 Ser. 103, 151-164.

4 Troussellier, M., Courties, C., Zettelmaier S., 1995. Flow cytometric analysis of coastal

5 lagoon bacterioplankton and picophytoplankton: fixation and storage effects. Estuar. Coast.

6 Shelf Sci. 40, 621-633.

7 Vadstein, O.A., Olsen, Y., 1989. Chemical composition and phosphate uptake kinetics of 8 limnetic bacterial communities cultured in chemostats under phosphorus limitation. Limnol.

9 Oceanogr. 34, 1989, 939-946.

10 Vaquer, A., Troussellier, M., Courties, C., Bibent, B., 1996. Standing stock and dynamics of 11 picophytoplankton in the Thau lagoon (northwest Mediterranean coast). Limnol. Oceanogr. $12 \quad 41,1821-1828$.

13 Wood, E.D., Armstrong, F.A.J., Richard, F.A., 1967. Determination of nitrate in sea water by 14 cadmium copper-reduction to nitrite. J. Mar. Biol. Ass. U.K. 47, 23-31.

15 Yamamoto, T., Tarutani, K., 1996. Growth and phosphate uptake kinetics of Alexandrium 16 tamarense from Mikaya Bay, Japan. In: Yasumoto, T., Oshima, Y., Fukuyo, Y. (Eds.), 17 Harmful and toxic algal blooms. IOC/UNESCO, Paris, pp. 293-296.

18 Yamamoto, T., Tarutani, K., 1999. Growth and phosphate uptake kinetics of the toxic 19 dinoflagellate Alexandrium tamarense from Hiroshima Bay, Japan. Phycol. Res. 47, 27-32. 
1 Table 1. Seasonal trends in mean cell densities $\left(10^{6}\right.$ cells/l) at different seasons for

2 Skeletonema costatum in Thau lagoon. Surface samples from station B. Numbers in

3 parentheses denote number of observations. Maximal values in bold.

4

5

6 Year

WINTER SPRING SUMMER FALL

7

$\begin{array}{llllllllll}8 & 1999 & 0.12 & (9) & \mathbf{3 . 2} & \text { (8) } & 0.22 & \text { (6) } & \mathbf{0 . 0 7} & \text { (7) }\end{array}$

$\begin{array}{llllllllll}9 & 2000 & 1.01 & (9) & 1.2 & \text { (7) } & \mathbf{0 . 4 9} & \text { (10) } & 0.00 & \text { (6) }\end{array}$

$\begin{array}{llllllllll}10 & 2001 & 0.27 & (6) & 0.5 & \text { (7) } & 0.13 & \text { (6) } & 0.03 & \text { (7) }\end{array}$

$\begin{array}{llllllllll}11 & 2002 & 0.26 & (6) & 0.16 & \text { (7) } & 0.27 & \text { (7) } & 0.07 & \text { (7) }\end{array}$

$\begin{array}{llllllllll}12 & 2003 & 0.01 & (7) & 0.003 & (6) & 0.003 & \text { (6) } & 0.02 & \text { (7) }\end{array}$

$\begin{array}{llllllllll}13 & 2004 & 0.04 & (6) & 0.08 & (8) & 0.013 & \text { (7) } & 0.002 & \text { (6) }\end{array}$

$14 \quad 2005 \quad 0.003 \quad(7) \quad 0.0002 \quad(6) \quad 0.014 \quad(7) \quad 0.014 \quad(6)$

$\begin{array}{lllllllll}15 & 2006 & \mathbf{2 . 2 8} & (7) & 0.001 & (7) & 0.012 & \text { (6) } & 0.0006\end{array}$

16

17

18

19

20

21

22

23

24

25 
1 Table 2. Half-saturation constants for soluble reactive phosphorus $\left(\mathrm{K}_{\mathrm{SRP}}\right)$ during uptake by

2 unicellular algae. Data from compilations by Lehman et al. (1975), Nalewajko and Lean

3 (1980), Doremus (1982), Cembella et al. (1984), Vadstein \& Olsen (1989), Donald et al.

4 (1997), Smayda (1997b) and Fu et al. (2006), with additional data from Fu et al. (2005),

5 Kromkamp et al. (1989), Isvanovics et al. (2000), Moutin et al. (2002, 2005), Yamamoto \&

6 Tarutani $(1996,1999)$. Data selected for maximum SRP additions of $20 \mu \mathrm{M}$. « All » refers to

7 both nutrient depleted and nutrient replete conditions.

8

9

10

11

12

Class

conditions

n

$\mathrm{K}_{\mathrm{SRP}}$

13

14

15

16

17

18

19

20

21

22

Euglenophyceae

23

Prymnesiophyceae

24

Raphidophyceae
All

$\mathrm{P}$ deficient

All

$\mathrm{P}$ deficient

All

$\mathrm{P}$ deficient

All

$\mathrm{P}$ deficient

All

All

All
2.5

2.6

29

0.7

20

0.7

24

1.3

19

1.3

13

1.8

8

2.4

\section{5}

4.6

3

1.3

3

1.7 
Figure captions

1. Study site and station locations. Urban areas in black, shellfish farming areas in grey.

2. Mean seasonal surface water temperature $\left({ }^{\circ} \mathrm{C}\right)$ in Thau lagoon as a function of time. Average values from between 2 and 11 stations depending on year.

3. Rainfall events, nitrate and chlorophyll a concentrations in Thau lagoon in 1993. Open diamonds: rainfall $(\mathrm{cm})$; open circles: nitrate $(\mu \mathrm{M})$; black triangles: chlorophyll a $(\mu \mathrm{g} / \mathrm{l})$

4. Soluble reactive phosphorus ( $\mu \mathrm{M}$; black squares), Synechococcus (Syne, $10^{8}$ cells/l; open circles), Alexandrium catenella (A. cat, $10^{6}$ cells/l; open triangles) and Skeletonema costatum (S. cost, $10^{5}$ cells/1; diamonds, no data before 1987) cell densities.

5. Chlorophyll a concentration (Chl-a) vs. total phosphorus concentration (TP) in 23 French Mediterranean lagoon waters. Values correspond to medians of pooled summer values (June, July and August) from 1998 to 2003 (From Souchu et al., in prep) for the Ifremer network "Réseau de Suivi Lagunaire" (http://www.rsl.cepralmar.com). Field observations allowed lagoons to be grouped according to the phanerogam-macroalgae and/or phytoplankton succession (Duarte, 1995; Schramm, 1999). The least eutrophicated lagoons correspond to transparent waters and a dominance of climax species such as phanerogams (stars). The next group still includes climax species but also proliferating macroalgae (squares). The next higher eutrophication level leads to the disappearance of climax species but proliferating macroalgae can still develop (diamonds). The final stage corresponds to the quasi-exclusive dominance of phytoplankton (triangles). Symbols within circles represent lagoons in which dinoflagellate $\mathrm{HAB}$ events have been recorded. 
6. Water temperature and Alexandrium catenella blooms occurring in spring (SPR) and in fall (FAL) from 2000 to 2003. Bloom events are shown as thick black horizontal lines. A: Spring events (Julian days 91 to 181, i.e. April to June); B: Fall events (Julian days 244 to 334 , i.e. September to November).

7. Mean Synechococcus cell densities $\left(10^{6}\right.$ cells/l; bars $)$ and mean water temperature $\left({ }^{\circ} \mathrm{C}\right.$; lines with circle symbol) in summer (2001-2006) at stations TE (black symbol) and TW (open symbol). 


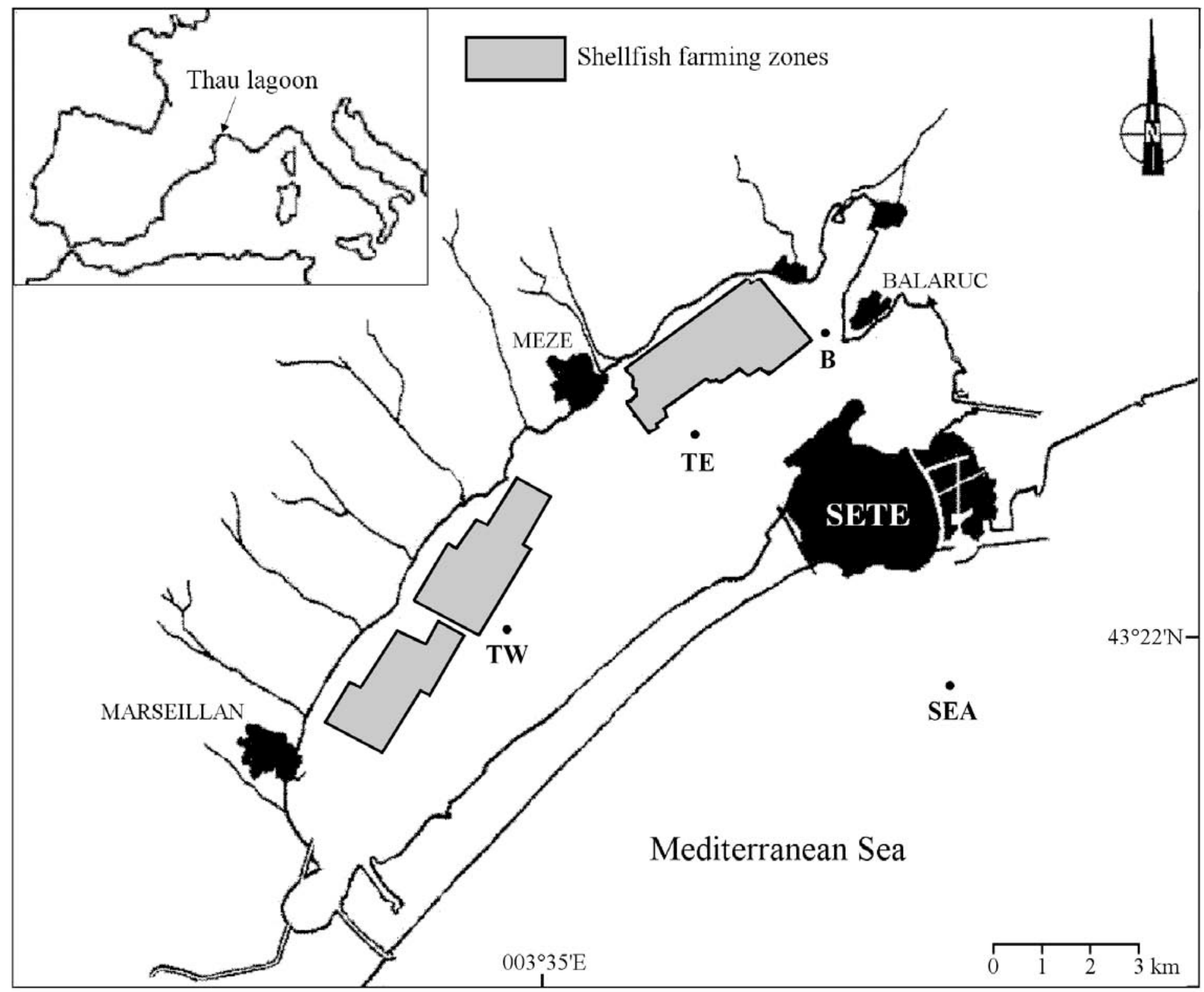




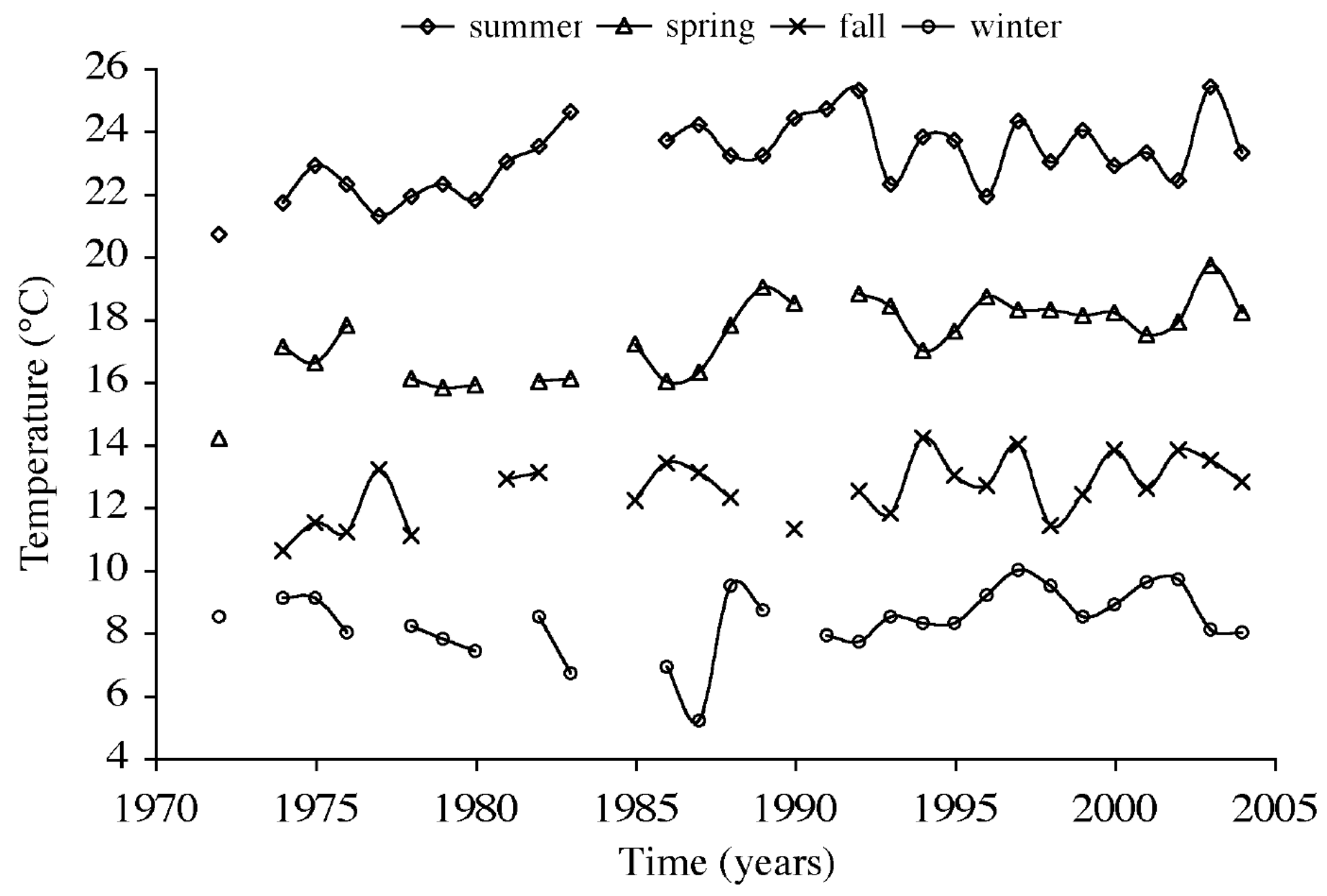




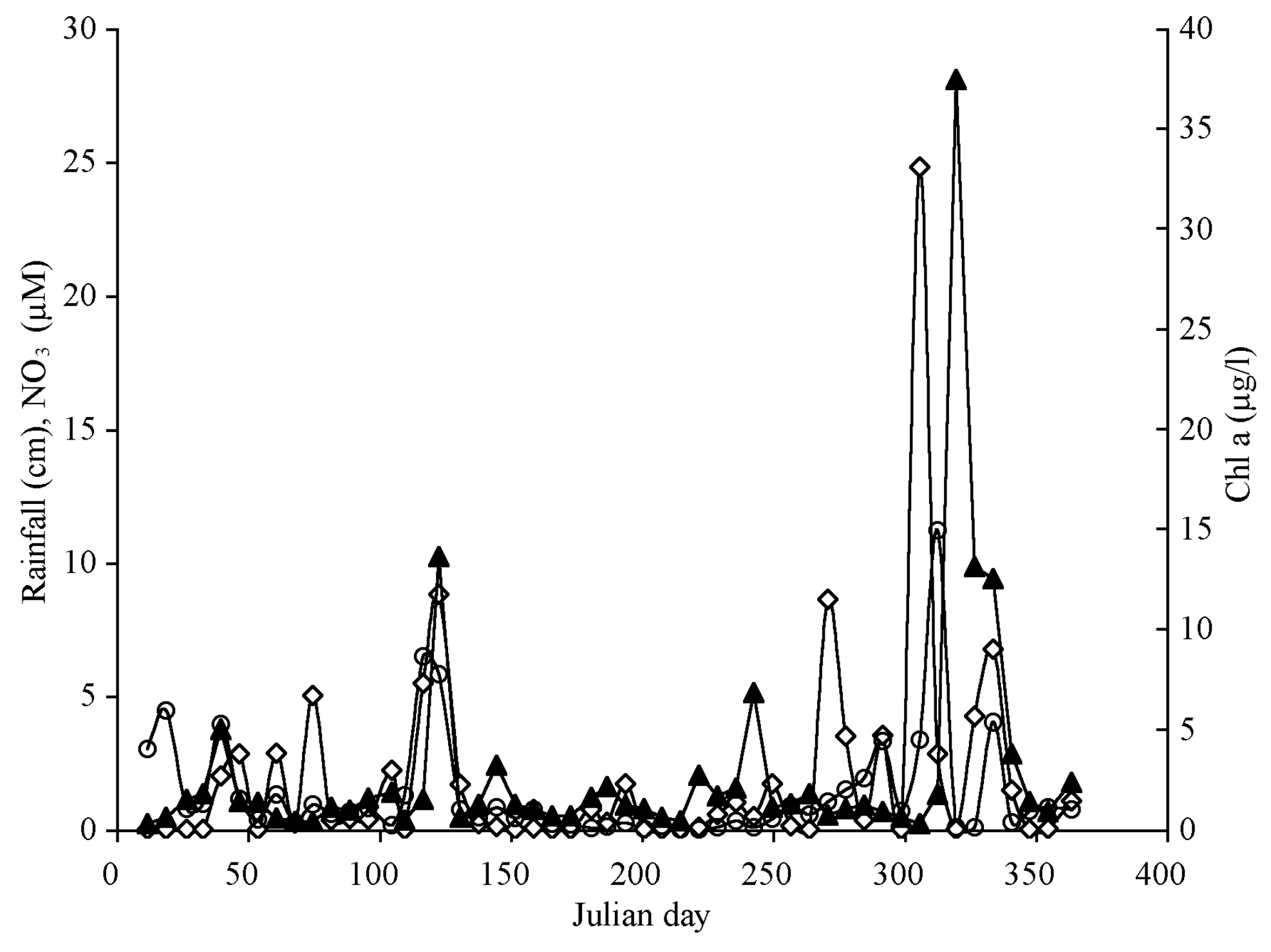




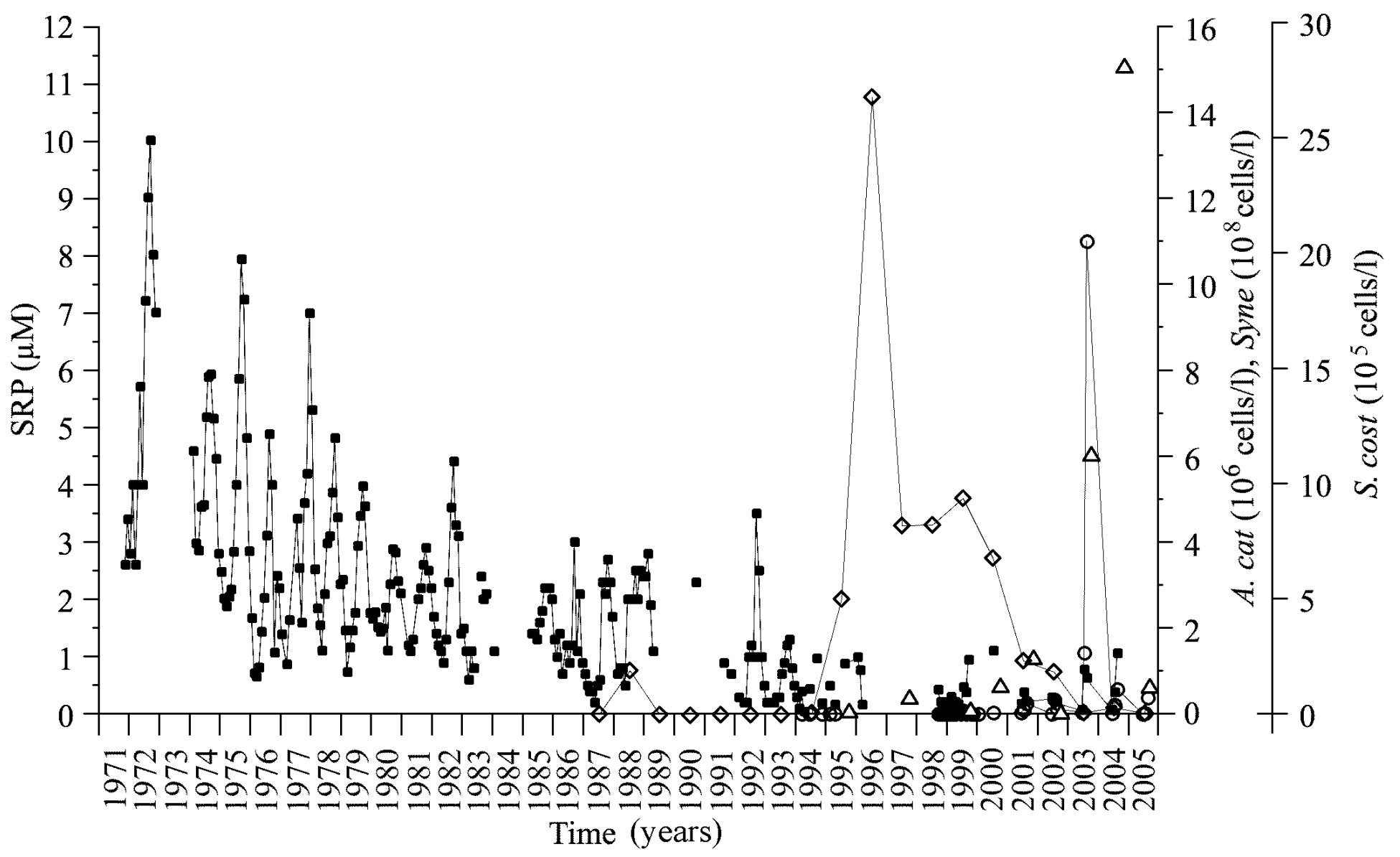




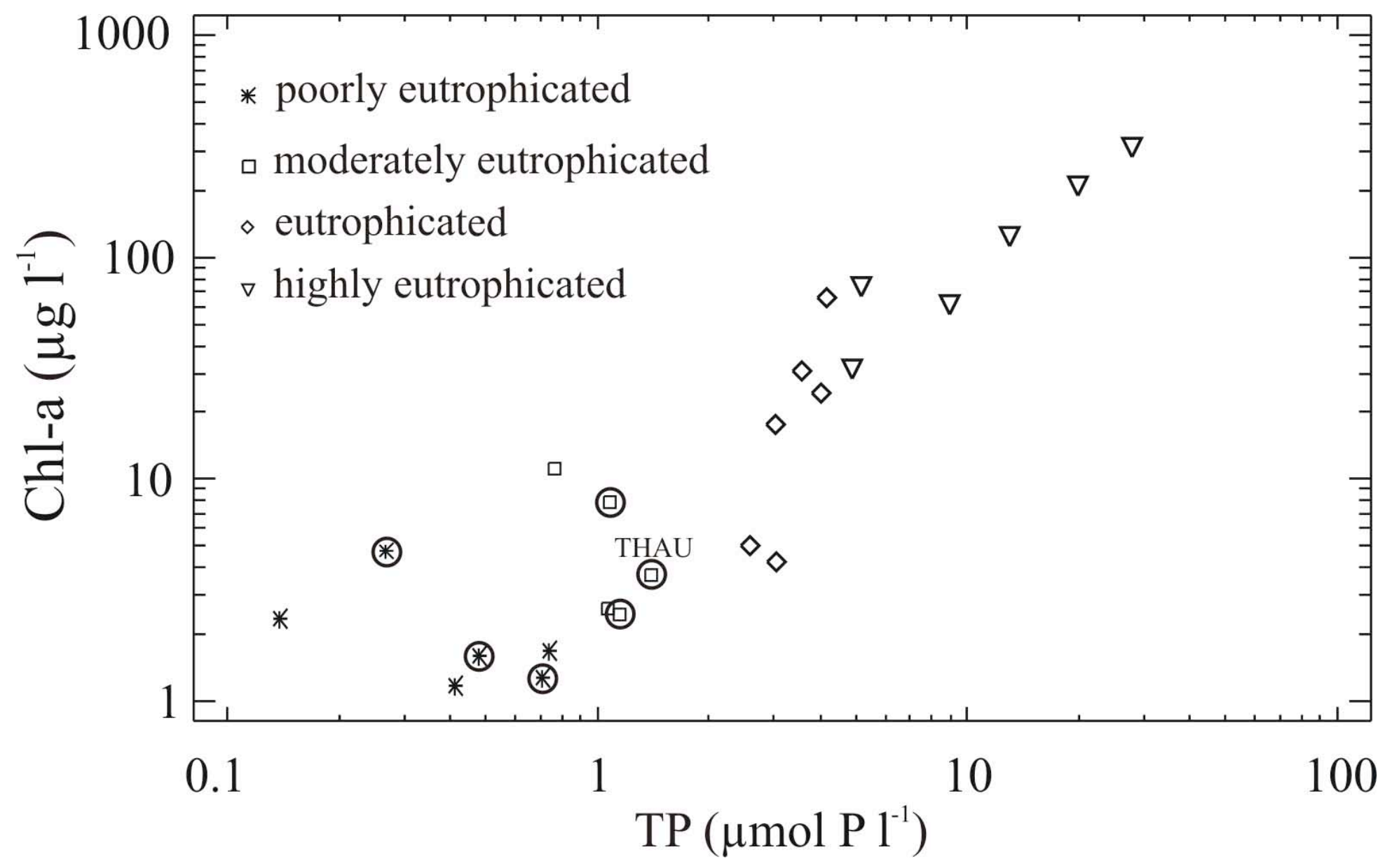



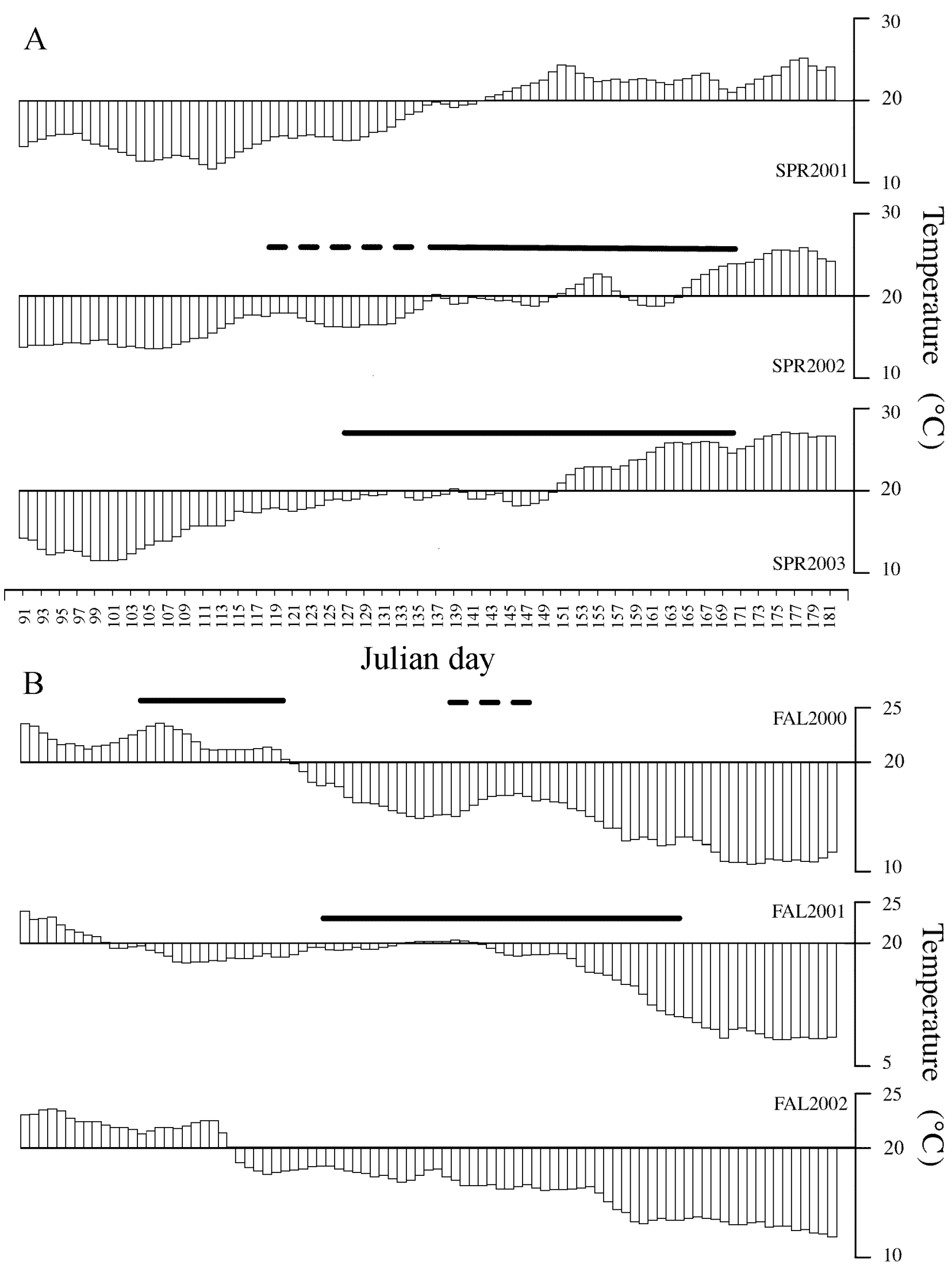

?̊

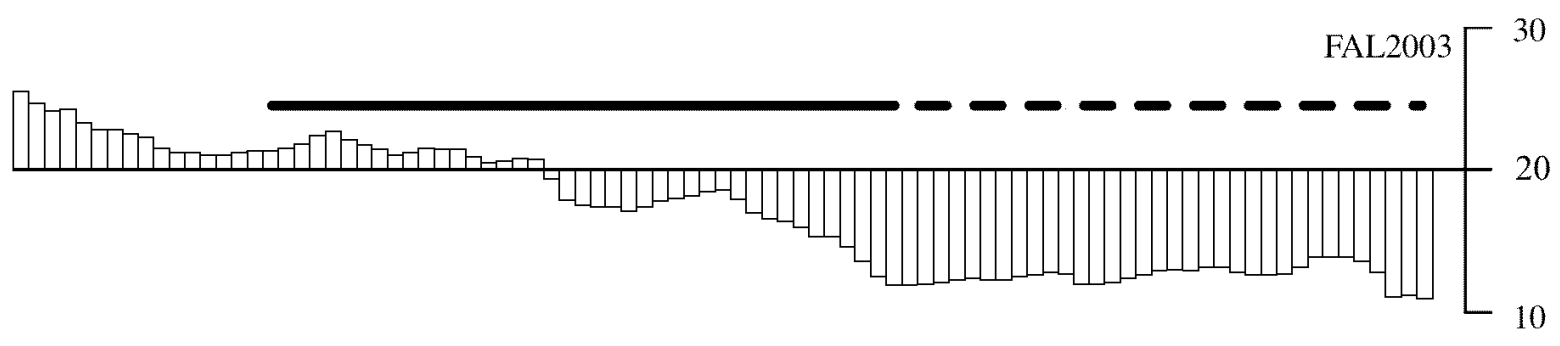

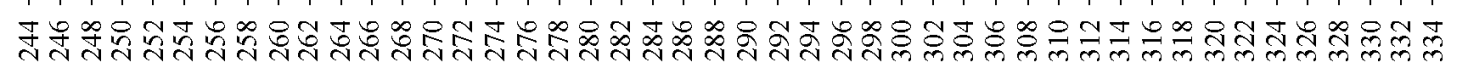




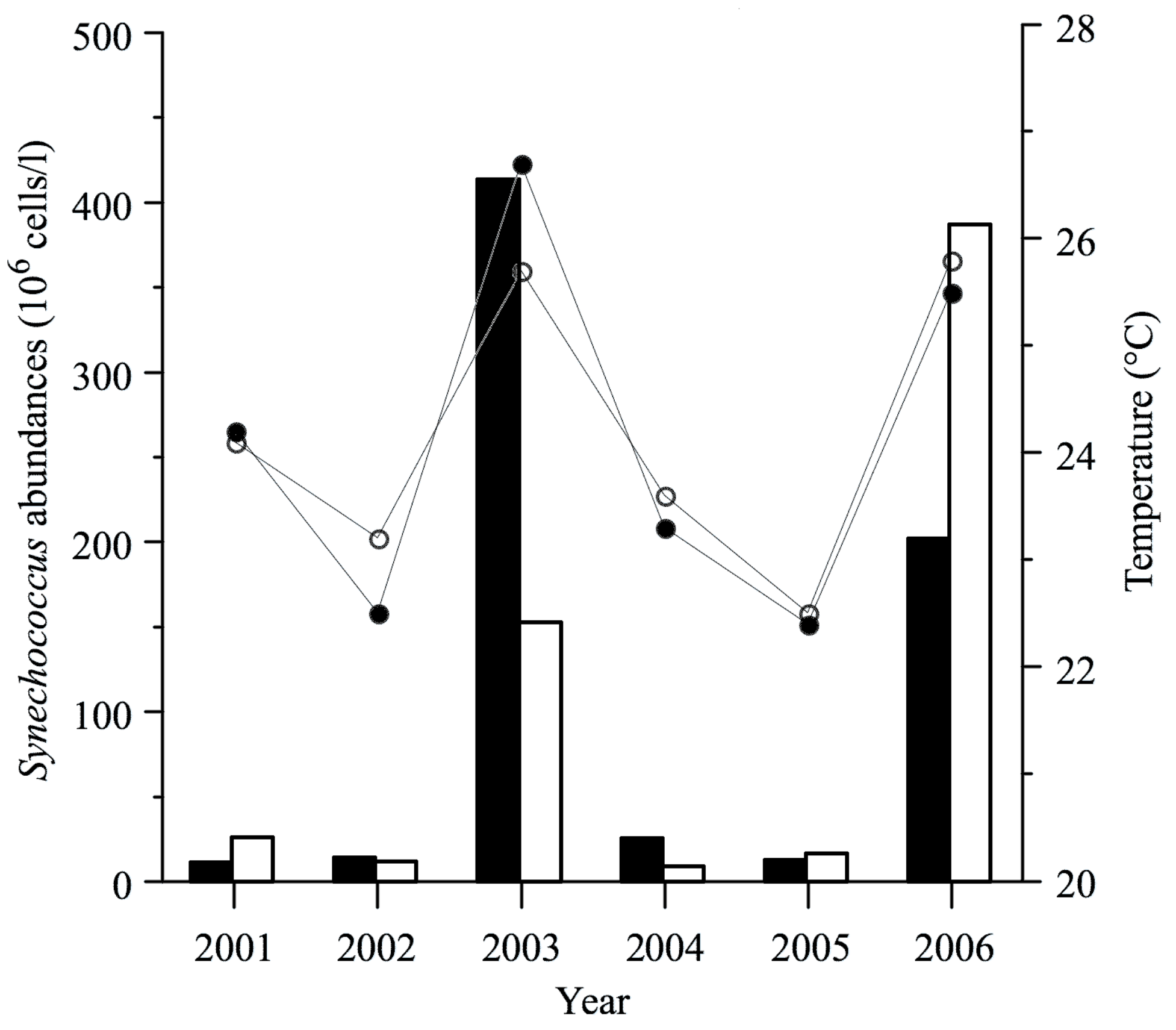

